\title{
Analysis of the Effect of Access Dimensions and Waiting Times on Satisfaction of Hospital Inpatients Prof. Dr. J.A. Latumen Ambon Level III Hospital
}

\author{
Stefanus G. Manuhuwa ${ }^{1}$, Sukri Palutturi' ${ }^{2}$, Amran Razak ${ }^{2}$, Darmawansyah ${ }^{2}$, \\ Saifuddin Sirajuddin ${ }^{3}$, Ridwan Mochtar Thaha ${ }^{4}$, Anwar Mallongi ${ }^{5}$ \\ ${ }^{1}$ Magister Student Program Department of Health Administration and Policy, Public Health Hasanuddin \\ University, ${ }^{2}$ Professor Department of Health Administration and Policy, Public Health Hasanuddin University, \\ ${ }^{3}$ Professor Department of Nutrition, Faculty of Public Health, Hasanuddin University, Indonesia, ${ }^{4}$ Senior Lecturer \\ Department of Health Promotion, Faculty of Public Health, Hasanuddin University, ${ }^{5}$ Department of Environmental \\ Health, Faculty of Public Health, Hasanuddin University
}

\begin{abstract}
Hospitals are as one of the health facilities to provide health services to the public and have a very important role in accelerating the improvement of the degree of public health. The purpose in this study is to analyze the Influence of Access Dimensions and waiting times on the satisfaction of inpatients at Level III Hospitals Prof. Dr. J.A. Latumen Ambon. The type of research used is quantitative research with cross sectional study design. The population in this study was 37,167 patients in the Inpatient installation in January-October 2019. The data analysis technique used is univariate and bivariate analysis, performed to look for the influence of each free variable with variables bound by using chi-square test. The results showed No accessibility affects the satisfaction of patients in Prof. Dr. J.A. Latumen Ambon Hospital. There is an effect of waiting time on patient satisfaction at Prof. Dr. J.A. Latumen Ambon Level III Hospital. It is very important for Prof. Dr. J.A. Latumen Ambon Level III Hospital to evaluate and improve the patient's complaints that trigger patients to feel dissatisfied with the hospital service.
\end{abstract}

Keywords: Access, Waiting Time, Satisfaction, Hospitalization, Hospital.

\section{Introduction}

In Indonesia, the health world is experiencing very significant development and has a pretty good prospect. These conditions make the competition more competitive. Therefore, every company engaged in the healthcare industry must be able to use various ways to attract customers through the quality of service ${ }^{1-2}$.

\section{Correspondence Author:}

\section{Stefanus G. Manuhuwa}

Magister Student Program Department of Health

Administration and Policy, Public Health Hasanuddin

University

e-mail: stefmanuhuwa@gmail.com
The higher the level of public education causes the public to become more aware of the importance of quality $^{3}$. People tend to demand better and faster health care. This has led to increasingly intense competition not only between fellow hospitals but also with health centers and health clinics in cities and in increasingly numerous areas ${ }^{4}$. Many healthcare providers are aware of this, so inevitably they have to realize the satisfaction of those customers in various strategies in order to be able to maintain customers ${ }^{5}$.

The quality of service and customer satisfaction were chosen as variables in this study because research on customer satisfaction is very important to research because customer satisfaction is the most often discussed issue in all Hospital patients ${ }^{6}$.Services provided by medical personnel or doctors are an integral part of the 
health service in the hospital, which has a very strategic position in an effort to improve the quality of service and satisfaction of consumers or patients coming to the hospital, which results in the satisfaction of the patient, organization or hospital ${ }^{7}$. Hospital Service Satisfaction depends heavily on the customer, If the customer no longer believes in the Hospital because of the poor results, then the Hospital will lose customer trust due to the poor response that was formed.

Hospitals are as one of the health facilities to provide health services to the public and have a very important role in accelerating the improvement of the degree of public health ${ }^{8-12}$. This requires health care providers, namely hospitals to improve the quality of better services, not only services that are disease-healing but also include preventive services. Therefore, hospitals are required to provide services that are in accordance with established standards and can reach all walks of life. ${ }^{13-16}$.

The quality of hospital services has two components, namely the fulfillment of the quality standards that have been set and the fulfillment of customer satisfaction. Hospitals should provide services that focus on customer satisfaction. Improvement in the quality of health care services can be started by evaluating every element that plays a role in shaping patient satisfaction. The health care system can be improved through clinical pathways, services, including patient perspectives such as how well health care services they need ${ }^{17}$.

Prof.dr. Level III Hospital J.A. Latumen is one of the Basic Health Governing Bodies of the XVI/ Pattimura military which has the main task of providing Health services to Indonesian National Army Personnel and Civil Servants of the Indonesian National Army and their families in the ranks of Regional Millitary Command XVI/Pattimura. Prof. dr. J.A. Latumen Level III Hospital is the highest referral hospital in the Regional Millitary Command XVI/Pattimura range of lower-level army Health Units. The number of visits of Prof. Dr. J.A. Latumen Ambon Level III Hospital in 2016 was 43,706, in 2017 43,305, in 2018 59,032 and the number of visits in October 2019 was 47,372 visits. from the data, inpatient visits experienced ups and downs. Patient perception of the quality of service with the level of patient satisfaction, especially for patients hospitalized level IIII Prof.Dr. J.A. Latumen Ambon is very important to improve better service ${ }^{18}$

The hospital needs to provide services in accordance with the patient's expectations ${ }^{19-21}$,Patient satisfaction depends on the quality of service with the appropriate service then the patient's expectations for the service of a service can be met or even exceeded its expectations, thus causing satisfaction in the patient, the patient's disappointment will arise if the performance of the health service obtained is not in accordance with the expectations ${ }^{10}$. In achieving patient satisfaction-oriented service objectives, it is important to note that it is important to determine the perception of patient quality, including facilities, the role of doctors, medical personnel and nurses ${ }^{22}$. The purpose in this study is to analyze the influence of access and waiting times dimensions on the satisfaction of inpatients in hospitals level III Prof. Dr. J.A. Latumen Ambon.

\section{Materials and Method}

The type of research used is quantitative research with cross sectional study design. The population in this study was 37,167 patients in the Inpatient installation in January-October 2019. The samples in his study were calculated using a large sample calculation according to Lameshow so that a large sample of 100 respondents was obtained. Technique of taking a sample using purposive samplin method. Data collection is obtained through interviews using computerized data processing questionnaires using the SPSS program. The data analysis technique used is univariate and bivariate analysis, performed to look for the influence of each free variable with variables bound by using chi-square test.

\section{Result}

Based on table 1 it is known that the characteristics of respondents based on the most age are the age group of $45-54$ years and 55 years and above which is 39 people $(39.0 \%)$. The characteristics of respondents based on the most gender are those with a male gender of 56 people $(56.0 \%)$. The characteristics of respondents based on the most recent education were those with higher education of 50 people $(50.0 \%)$ 
Table 1: Distribution of Respondents Based on Characteristics of Inpatient Respondents In Prof. Dr. J.A. Latumen Ambon Level III Hospital in 2020

\begin{tabular}{|l|c|c|}
\hline Characteristics & $\begin{array}{c}\text { Amount } \\
\text { (n) }\end{array}$ & $\begin{array}{c}\text { Percent } \\
\text { (\%) }\end{array}$ \\
\hline a. Age Group (yrs) & & \\
15-24 & 3 & 3.0 \\
$25-34$ & 6 & 60.0 \\
$35-44$ & 13 & 13.0 \\
$45-54$ & 39 & 39.0 \\
$55+$ & 39 & 39.0 \\
\hline b. TypexSex & & \\
Malex & 56 & 56.0 \\
Women. & 44 & 44.0 \\
\hline c. Education. & & \\
SD/equivalent & 1 & 1.0 \\
Junior High School/equivalent & 11 & 11.0 \\
SMA/equivalent & 38 & 38.0 \\
College & 50 & 50.0 \\
\hline Total & $\mathbf{1 0 0}$ & $\mathbf{1 0 0 . 0}$ \\
\hline
\end{tabular}

Source: Primary Data, 2020

Table 2: Frequency Distribution of Research Variables Inpatients at the Hospital In Prof. Dr. J.A. Latumen Ambon Level III Hospital in 2020

\begin{tabular}{|l|c|c|}
\hline Research variable & Amount (n) & Percent (\%) \\
\hline Access & 56 & 56 \\
Affordable & 44 & 44 \\
Unreachable & & \\
\hline Waiting time & 84 & 84 \\
Well & 16 & 16 \\
Not good & & \\
\hline Satisfaction & 57 & 57 \\
Satisfied & 43 & 43 \\
Not satisfied & & \\
\hline
\end{tabular}

Source: Primary Data, 2020
Based on Table 2 shows that of the 100 respondents in Prof. Dr. J.A. Latumen Ambon Hospital, 56 respondents (56.0) with affordable access and as many as 44 respondents $(44.0 \%)$ with unreachable access. Based on the waiting time variable shows that out of 100 respondents in Prof. Dr. J.A. Latumen Ambon Level III Hospital, 84 respondents (84.0\%) provide a good waiting time assessment and as many as 16 respondents $(16.0 \%)$ the waiting time assessment is not good. Based on satisfaction variables showed that out of 100 respondents at Prof. Dr. J.A. Latumen Ambon Level III Hospital, 57 respondents (57.0\%) assessment and 43 respondents (43.0\%) who give dissatisfied judgment

Table 3 shows that of the 56 respondents with affordable access, 36 respondents (64.3\%) satisfied and as many as 20 respondents (35.7\%) expressed dissatisfaction. Meanwhile, of the 44 respondents with unaffordable access, 21 respondents (47.7\%) satisfied and as many as 23 respondents (52.3\%) expressed dissatisfaction. Statistical test results obtained a value of $p=0.097$, since the value $p>\alpha=0.097>0.05$ then Ho is accepted, this means that there is no statistically meaningful influence of accessibility variables on patient satisfaction in Prof. Dr. J.A. Latumen Ambon Level IIII Hospital.

Based on waiting time variables shows that of the 84 respondents with a good assessment of waiting time as many as 56 respondents (64.3\%) satisfied and as many as 30 respondents $(35.7 \%)$ expressed dissatisfaction. Meanwhile, of the 16 respondents with poor rating on waiting times, 3 respondents (18.8\%) satisfied and as many as 13 respondents (81.2\%) expressed dissatisfaction. Statistical test results obtained a value of $p=0.001$, because the value $p<\alpha=0.001<0.05$ then $\mathrm{H} 0$ is rejected, this means that there is a statistically meaningful influence of waiting time variables on patient satisfaction in Prof. Dr. J.A. Latumen Ambon Level IIII Hospital. 
Table 3: Results of the Chi Square Test for Research Variables on Inpatient Satisfaction at In Prof. Dr. J.A. Latumen Ambon Level III Hospital in 2020

\begin{tabular}{|c|c|c|c|c|c|c|c|}
\hline \multirow{3}{*}{ Variable } & \multicolumn{4}{|c|}{ Patient Satisfaction } & \multirow{2}{*}{\multicolumn{2}{|c|}{ Total }} & \multirow{3}{*}{$\mathbf{P}$} \\
\hline & \multicolumn{2}{|c|}{ Satisfied } & \multicolumn{2}{|c|}{ Not satisfied } & & & \\
\hline & $\mathbf{N}$ & $\%$ & n & $\%$ & $\mathbf{n}$ & $\%$ & \\
\hline Access & & & & & & & \\
\hline Affordable & 36 & 64.3 & 20 & 35.7 & 56 & 100 & 0.097 \\
\hline Unreachable & 21 & 47.7 & 23 & 52.3 & 44 & 100 & \\
\hline Waiting time & & & & & & & \\
\hline Well & 54 & 64.3 & 30 & 35.7 & 84 & 100 & 0.001 \\
\hline Not good & 3 & 18.8 & 13 & 81.2 & 16 & 100 & \\
\hline
\end{tabular}

Source: Primary Data, 2020

\section{Discussion}

Good access is that health care should be achievable to the community, not hindered by geographical, social, economic, organizational and language circumstances. Geographic access is measured by distance, length of travel, cost of travel, type of transportation, and other physical barriers that can deter a person from getting health care. The access dimension can measure the quality of service about how patients reach the desired health service, whether the access is good or not so from here that will later cause satisfaction in patients ${ }^{23-24}$. The location of the hospital where they are undergoing treatment is difficult to access because it feels the distance traveled by far and most respondents already do not have a private vehicle and the language used by health workers is not easy to understand. Meanwhile, respondents who felt good access or service were easily accessible because their location of residence was close to the hospital and already owned a private vehicle.

This research is in line with herman et al research which shows that there is no relationship of quality of service access (affordability) with patient satisfaction ( $\rho$ $=0.057)^{25}$. Another in line study was conducted balqis et al where the results of the chi square test analysis obtained a value of $p=0.525$, because the value of $p \geq 0.05$ means it can be concluded that there is no relationship between affordability or access to the quality of service ${ }^{26}$.. This research is not in line with this research in line with rivai et al research which highlights the Dimensions of affordability/access to services $(\mathrm{p}=0,177)^{27}$.

The waiting times in this study include the time that patients use to get health care from enrollment to admission to a doctor or nurse. As the theory of waiting time is the time that patients use to get health care starting from the place of registration to get doctor's care. The results showed that patients were satisfied with waiting times related to fast file or file preparation skills, user satisfaction that used SIMRS in managing data and providing health care, both in terms of efficiency, effectiveness, satisfaction, but still patients who were dissatisfied with the discipline of doctors who came in was not on time.

Satisfaction of users who use SIMRS in managing data and providing health care, both in terms of efficiency, effectiveness, satisfaction.

His research is in line with research conducted by Laeliyahe et al which showed a link between the waiting times for patients in the outpatients and the satisfaction of patients in the hospital's hospital services, with a score of $0.042^{29}$. his proves that with long waiting times for outpatient services there will be increasing dissatisfaction with patients' dissatisfaction with outpatient services, and vice versa ${ }^{30-32}$.

\section{Conclusion}

This study concluded that There is no accessibility effect on patient satisfaction in Prof. Dr. J.A. Latumen Ambon Hospital. There is an influence of waiting time on patient satisfaction at Prof. Dr. J.A. Latumen Ambon Level IIII Hospital. It is very important for Prof. Dr. J.A. Latumen Ambon Level IIII Hospital to evaluate and improve the patient's complaints that trigger patients to feel dissatisfied with hospital services 
Ethical Clearance: Taken from University ethical clearance committee.

\section{Source of Funding: Self}

\section{Conflict of Interest: Nil.}

\section{References}

1. Supriyanto Y, Soesanto H. Analisis pengaruh kualitas pelayanan, harga, dan fasilitas terhadap kepuasan pasien rawat jalan di Rumah Sakit Kariadi Semarang, Fakultas Ekonomika dan Bisnis; 2012.

2. Tahir M, Amiruddin R, Palutturi S, Rivai F, Saleh LM. The relationship between organizing and leadership style and the quality improvement of primary healthcare services. Enfermería Clínica. 2020;30:39-43.

3. Pirade FL, Razak A. Relationship Analysis between the Quality of Health Services and Patients Satisfaction in Kapasa Health Center Makassar City. Indian Journal of Public Health Research \& Development. 2019;10(7):1100-1104.

4. Datuan N, Darmawansyah D, Daud A. PENGARUH KUALITAS PELAYANAN KESEHATAN TERHADAP KEPUASAN PASIEN PESERTA BPJS DI RUMAH SAKIT UMUM DAERAH HAJI MAKASSAR. Jurnal Kesehatan Masyarakat Maritim. 2019;1(3).

5. Lubis AN. Pengaruh Harga (Price) dan Kualitas Pelayanan (Service Quality) Terhadap Kepuasan Pasien Rawat Inap di RSU Deli Medan. Jurnal Manajemen Bisnis. 2009;2:21-24.

6. Arifin A, Nursakinah N, Darmawansyah, Sirajuddin S, Marzuki DS. The Effect of Technical and Functional of Health Service Quality Toward the Image of Faisal Islamic Hospital. Indian Journal of Public Health Research \& Development. 2018;9(6):357-361.

7. Anwar AA, Rahmadani S, Rochka MM. ANALISIS PENGARUH CLINICAL AUTONOMY TERHADAP KEPUASAN KERJA DOKTER ERA JKN DI RSUD KOTA MAKASSAR. VISIKES: Jurnal Kesehatan Masyarakat. 2019;18(2).

8. Sitorus J, Jafar N, Amiruddin R, Palutturi S, Hadju V, Wisudawan O. Characteristics of Outpatient Pre Diabetes Dr. Dody Sarjoto Hospital, Maros Regency, South Sulawesi, Indonesia. Indian Journal of Public Health Research \& Development. 2020;11(3):2058-2061.
9. Rusydi AR, Palutturi S, Noor NB, Pasinringi SA. The comparison of good corporate governance on human resources performance in regional general hospital of Labuang Baji and Ibnu Sina hospital Makassar, South Sulawesi. Enfermería Clínica. 2020;30:482-486.

10. Lamri L, Setyadi DS, Riadi SSR, Hariyadi S, Palutturi SP. Determinants of Organizational Citizenship Behavior, Work Satisfaction and Performance of the Eselon IV Officials of Regional General Hospitals in East Kalimantan Province. Journal of Arts and Humanities. 2020;9(4):88-97.

11. Supriadi S, Minarti SMS, Paminto APA, Hidayati THT, Palutturi SPS. Factors related to Nurses' Job Satisfaction and Performance at Private Hospitals in Samarinda City, Indonesia. Journal of Arts and Humanities. 2020;9(6):42-52.

12. Nahlah A, Palutturi S, Abadi MY. Factors Related to the Satisfaction of Patients in Pelamonia Hospital. SCOPUS IJPHRD CITATION SCORE. 2019;10(7):1191.

13. Handayani $\mathrm{S}$, Iriyanto $\mathrm{S}$. Pengaruh kualitas pelayanan dan tarif terhadap kepuasan serta implikasinya terhadap minat beli pasien rawat inap pada Rumah Sakit Roemani Muhammadiyah Semarang. Jurnal stiedharmaputra. 2010;3(2):1.

14. Sadakah S, Palutturi S, Pasinringi SA, Sidin AI, Amiruddin R, Saleh LM. The implementation of the value of local philosophy on nurse performance in bima regional general hospital, Indonesia. Enfermería Clínica. 2020;30:478-481.

15. Said M, Palutturi S. Increasing inpatient service quality of using quality function deployment method in nene mallomo hospital of sidrap regency, Indonesia. Indian Journal of Public Health Research \& Development. 2018;9(4):287-291.

16. Amir MY, Palutturi S. Legal Aspects of Emergency Medical Services Department of Wahidin Sudirohusodo Hospital, Makassar Indonesia. Indian Journal of Public Health Research \& Development. 2018;9(5):16-20.

17. Kartikasari D, Dewanto A, Rochman F. Pengaruh kualitas layanan terhadap kepuasan dan kepercayaan di rumah sakit bunda Kandangan Surabaya. Jurnal Aplikasi Manajemen. 2014;12(3):454-463.

18. Profil Rumah Sakit. Profil Rumah Sakit Tingkat III Prof. dr. J.A. Latumeten. Ambon: Rumah Sakit Tingkat III Prof. dr. J.A. Latumeten;2019. 
19. Hafsa AM, Maidin A, Sukri Palutturi S. Regionalization Referral System of the Hospital National Health Insurance. Indian Journal of Public Health Research \& Development. 2020;11(3):14221427.

20. Lammade AH, Hamzah A, Palutturi S. Relationship of Marketing Mixes with the Return Interest of Patients at ArifinNu'mang Hospital. SCOPUS IJPHRD CITATION SCORE. 2019;10(7):1095.

21. Muin H, Palutturi S, Sirajuddin S. User Satisfaction about the Use of SIMRS on Performance of Street Units in Nene Mallomo Hospital Sidenreng Rappang Regency. 2019.

22. Maidin A, Sidin I, Rivai F, Palutturi S. Patient satisfaction based on Bugis philosophy at the Siwa Hospital in Wajo District, South Sulawesi. Enfermería Clínica. 2020;30:141-144.

23. Arifin A, Arifin MA, Abadi Y, Marzuki DS, Rahmadani S, Fajrin MA. Accessibility of Availability of Public Health Services Dayak Tribe in Samarinda "Qualitative Study". Indian Journal of Public Health Research \& Development. 2019;10(10):1514-1518.

24. Adrianto R, Razak A, Maidin MA. The Accessibility of Health Services for Multiethnics Community Towards Universal Health Coverage in Samarinda City: A Qualitative Study. Indian Journal of Public Health Research \& Development. 2019;10(10):1363-1367.

25. Herman H, Sudirman S, Nizmayanun N. Hubungan Kualitas Pelayanan Kesehatan Dengan Kepuasan Pasien Rawat Jalan Di Puskesmas Lembasada Kabupaten Donggala. Preventif: Jurnal Kesehatan Masyarakat. 2014;5(2).

26. Balqis B, Amir MY, Hardianti U. Faktor yang Berhubungan dengan Mutu Pelayanan Antenatal di Puskesmas Pattingalloang Kota Makassar. Jurnal
Administrasi dan Kebijakan Kesehatan Indonesia. 2013;2(02):8268.

27. Rivai F, Lestari S, Shaleh K. Hubungan Mutu Pelayanan dengan Kepuasan Pasien di Instalasi Rawat Inap Rumah Sakit Ibnu Sina YWUMI. Media Kesehatan Masyarakat Indonesia. 2020;16(1):38-47.

28. Muin H, Palutturi S, Sirajuddin S, Mallongi A, Syam A. User's satisfaction about the use of simrs performance of outpatient units in nene mallomo hospital sidenreng rappang regency. Enfermería Clínica. 2020;30:388-391.

29. Laeliyah N, Subekti H. Waktu Tunggu Pelayanan Rawat Jalan dengan Kepuasan Pasien Terhadap Pelayanan di Rawat Jalan RSUD Kabupaten Indramayu. Jurnal Kesehatan Vokasional. 2017;1(2):102-112.

1.1 30. Anwar Mallongi, Agus Bintara Birawida, Ratna Dwi Puji Astuti, Muh Saleh, Effect of lead and cadmium to blood pressure on communities along coastal areas of Makassar, Indonesia. Enfermería Clínica., Volume 30, Supplement 4, June 2020, Pages 313-317

31. Anwar Mallongi, Stang, Syamsuar, Muh Fajaruddin Natsir, Ratna Dwi Puji Astuti, Annisa Utami Rauf, Muhammad Rachmat, Abdul Muhithd, Potential ecological risks of mercury contamination along communities area in tonasa cement industry Pangkep, Indonesia. Enfermería Clínica., Volume 30, Supplement 4, June 2020, Pages 119-122

32. Anwar Mallongi, Ezra Limbong, Furqaan Naiem, Hasanuddin Ishak, Syahrul Basri, Muh. Saleh, Aminuddin Syam, Laode Asrul. Health risk analysis of exposure to mercury $(\mathrm{Hg})$ and cyanide (CN) in Kayeli village communities Teluk Kayeli district Buru regency. Enfermería ClínicaVolume 30, Supplement 4, June 2020, Pages 427-430 